\title{
POWARs: Notes for guidance
}

These notes, prepared by the $B M A$, will be sent to place of work representatives (POWARs) service (see leading article, $p$ 1180). It is planned to produce audiovisual packs and to arrange training courses for POWARs.

(1) The following is a brief informal summary of the commitments involved in becoming a BMA place-of-work accredited representative (POWAR), for the information of those who may be interested in taking on this task. It is not an official statement of duties nor is it a statement of accreditation.

\section{Man on the spot}

(2) The POWAR will be the BMA "man" at the most local level-that is, the hospital or work place. He will need to be readily and regularly available to BMA members, to listen, sift, answer, or route their problems.

\section{Part of the peripheral organisation}

(3) The POWAR will be part of the BMA peripheral organisation. This includes provincial medical secretaries and regional officers and from 1979 will, as part of an expanded industrial relations service, include regional industrial relations officers, all of whom are permanent paid staff, available to give assistance as needed. The POWAR will also need to keep in close touch with the division honorary secretary and with other honorary officers.

\section{Duties}

(4) The POWAR's duties will vary in detail from place to place but will essentially fall into two categories : the hospital work place, who will welcome and look after the interest of members and recruit new members to the BMA. In this he will work in close co-operation with the division honorary secretary.

(2) As the local representative of the BMA in a trade union capacity. This does not just mean if and when there is a major dispute, who will initially be appointed in the hospital

(1) As the local BMA representative in

giving rise to what is termed "industrial accredited union representative alone is protected in law if he acts on behalf of the union. It is much more a question of seeing that individual members of the BMA are aware of the terms and conditions of service they should enjoy and that they derive full benefit from the various protective measures which are embodied in recent employment legislation. For this, the POWAR will need to have an outline knowledge of the main aspects of this legislation, which he will gain with experience.

\section{Time off}

\section{Talking point-continued}

financial adjustments. The "fee for service" method of payment, though initially attractive as it rewards actual effort, must be balanced against the level of controls, regulations, bureaucracy, and apparent reduced personal freedom which would follow from its implementation.

I would like to thank the King's Fund College, London, particularly Mr P Torrie (director) and $\mathrm{Mr}$ W Fraser (senior tutor); Professor Maureen Dixon, Department of Health Administration, University of Toronto; and Dr Gerald Gold, director, Professional Services Monitoring Branch, Ontario Ministry of Health, for his help in preparing this article. action," although if this were to happen the

$\mathrm{He}$ may be able to sort out some of the members' problems on the spot but he wil also need to be in close touch with, and able to contact quickly, those who by virtue of their job have a more detailed knowledge of these matters-the regional industrial relations officer and the provincial medical secretary, who in turn can call upon the staff of the operational branch at headquarters. Any POWAR who feels uneasy about embarking on a particular course of action should contact the regional industrial relations officer or provincial medical secretary.

(5) Much of this activity can best be conducted informally when off duty in a relaxed atmosphere-for example, in the hospital mess. However, it is worth noting that the ACAS Code of Practice 3, "Time off for Trade Union duties and activities," which came into effect in April 1978 (and which will be incorporated in a General Whitley Council agreement) provides, in para 13, that a trade union officia is permitted to take reasonable paid time of during working hours for such purposes as:

(a) collective bargaining with the appropriate level of management;

(b) informing constituents about negotiations or consultations with management

(c) meetings with other lay officials or with full-time union officers on matters which are concerned with industrial relations between his or her employer and any associated employer and their employees;

$(d)$ interviews with and on behalf of constituents on grievance and discipline matter concerning them and their employer;

(e) appearing on behalf of constituents before an outside official body, such as an industrial tribunal, which is dealing with an industrial relations matter concerning the employer; and

$(f)$ explanations to new employees whom he or she will represent of the role of the union in the work place industrial relations structure.

It does not follow that the BMA will necessarily want every POWAR to carry out all these duties, and in particular it is unlikely that he will be expected to appear before an industrial tribunal. Many of the duties listed will in practice be undertaken by either the industrial relations officer or the provincial medical secretary.

\section{Facilities}

(6) Early in 1976 the DHSS issued a circular (Advance letter (GC)2/76) on a General Whitley Council agreement on "Facilities for Staff Organisations." This will be superseded by the new agreement when it isissued. Meanwhile the ACAS Code 3 says: "Management should make available to officials the facilities necessary for them to perform their duties efficiently and to communicate effectively with members, fellow lay officials and full-time officers. Such facilities may include accommodation for meetings, access to a telephone, notice boards, and, where the volume of the official's work justifies it, the use of office facilities." (para 24).

Where a POWAR feels that he could usefully take advantage of this kind of facility, he should make arrangements with the employing authority directly.

\section{Help with taxation}

The BMA's accounts department has revised its series of taxation leaflets. There are five -(1) General principles; (2) Income taxSchedule D; (3) Income tax-Schedule E; (4) Capital gains tax; and (5) Retirement annuity contracts. The leaflets are intended as a guide to doctors and are not meant to be used as a substitute for consulting accountants. The BMA plans to revise them every three years, with brief notes in the intervening period explaining the more important fiscal changes. BMA members who would like copies should apply to BMA House quoting their membership number.

\section{References}

${ }^{1}$ Backley, W Alan, The Health System in Ontario, personal paper to King's Fund College Course May 1978.

2 Gold, G, Ontario Health Insurance Plan Bulletin December 1976.

3 Ontario Drug Benefit Formulary, 1978.

4 Ontario Medical Association, Schedule of Fees, 1977.

5 The Government of Ontario Insurance Act 1972 (amended 1974).

${ }^{6}$ British Medical fournal, 1978, 2, 135.

7 British Medical fournal, 1978, 2, 298.

(Accepted 3 October 1978)

\section{Correction}

\section{From the CCCM}

We regret that in the report of the proceedings of the Central Committee for Community Medicine (7 October, p 1040) we said that Dr Anne Jepson represented the Association of Clinical Medical Officers. In fact Dr Jepson is a member of the Faculty of Community Medicine and of the Association of Specialists in Community Medicine (Child Health). 